\title{
Fertility of Aneuploids between the 5x and 6x Levels in Blueberry: The Potential for Gene Transfer from $4 x$ to $6 x$ Levels
}

\author{
Timothy Laverty and N. Vorsa \\ Blueberry and Cranberry Research Center, Rutgers University, Chatswotih, NJ 08019 \\ Additional index words. pentaploid, hexaploid, aneuploidy, blueberry breeding, Vaccinium corymbosum, V. ashei
}

\begin{abstract}
Vaccinium ashei (6x)/V. corymbosum (4x) pentaploid hybrids backcrossed to $V$. ashei yield aneuploid progeny ranging in chromosome number from $5 x$ to $6 x$ levels. Six backcross aneuploids having chromosome numbers of $2 \mathrm{n}=61,62,64,66,68$, and 70 were selected from this backcross and crossed in a complete diallel mating design and backcrossed (as female parents) to two $V$. ashei cultivars and an interspecific hexaploid hybrid. Fertility variables measured were percent fruit set, total seed per berry, developed seed per berry, percent developed seed per berry, percent seed germination, developed seed per pollination, and seedlings per pollination. A significant linear and positive relationship was found between chromosome number and all seven fertility variables. However, regression accounted for $30 \%$ or less of the variation among crosses. Diallel analysis revealed that general combining ability was the major contributing effect for all seven variables, followed by reciprocal effects. Specific combining ability was not significant. The second backcross to the hexaploid level suggested significant effects due to both the $\mathrm{BC}_{1}$ aneuploid and hexaploid genotypes and to a significant genotype $\times$ genotype interaction for three of the variables. All six aneuploids were either fully or partially self-sterile. The findings of this study substantiate earlier suggestions that pentaploids in blueberry can be used to facilitate bilateral transfer of characteristics between the tetraploid and hexaploid levels in blueberry.
\end{abstract}

In blueberry, genetic improvement has been directed at two ploidy levels that generally are considered reproductively isolated from one another. These are the tetraploid $(2 \mathrm{n}=4 \mathrm{x}=$ $48)$ and hexaploid $(2 n=6 x=72)$ chromosome levels. Genetic improvement at the tetraploid level has largely involved $\mathrm{Vac}$ cinium corymbosum L. ancestry, the highbush blueberry, while at the hexaploid level, it has largely involved $V$. ashei Reade ancestry, the rabbiteye blueberry. The possibility of bilateral gene transfer between these two species and the two ploidy levels these species represent would significantly broaden the germplasm base for genetic improvement programs in blueberry. The potential for direct gene transfer from the hexaploid to the tetraploid species by way of the pentaploid hybrid "bridge" between these two species has already been established (Vorsa et al., 1987b). Genetic improvement efforts in rabbiteye blueberry could benefit from the considerable germplasm that exists at the tetraploid level, which includes two domesticated species of blueberry, $V$. corymbosum and $V$. angustifolium Aiton. In particular, V. corymbosum could offer improved fruit quality, earlier fruit ripening (Galletta, 1975), and greater self-fertility (El-Agamy et al., 1981).

Transmission of the extra genome chromosomes was found to be enhanced, relative to what would be expected with random transmission, when the pentaploid hybrids were backcrossed to the hexaploid species (Vorsa, 1988). Chromosome numbers in $\mathrm{BC}_{1}$ seedlings ranged from hypopentaploid $(2 \mathrm{n}=4 \mathrm{x}+11=$ 59) to hexaploid, with means of $2 n=66.2$ and $2 n=68.0$ for the $5 \mathrm{x} \times 6 \mathrm{x}$ and $6 \mathrm{x} \times 5 \mathrm{x}$ progenies, respectively. More than $95 \%$ of the progeny were aneuploid, with $<2 \%$ being hexa-

Received for publication 29 May 1990. New Jersey Agricultural Experiment Station publication no. D-12163-5-90. We thank H.E. Schaffer for providing the DIALL software program and G. Jelenkovic, J.R. Ballington, P.M. Lyrene, and G.J. Galletta for their critical review and helpful suggestions. We also thank $\mathrm{H}$. Janes for providing greenhouse facilities. From a thesis submitted by T.L. in partial fulfillment of the requirements for the MS degree. The cost of publishing this paper was defrayed in part by the payment of page charges. Under postal regulations, this paper therefore must be hereby marked advertisement solely to indicate this fact. ploid. The predominant chromosome number class in $6 \mathrm{x} \times 5 \mathrm{x}$ crosses was the hypohexaploid number of $2 n=5 x+9=69$; however, a conspicuously predominant class in the $5 \mathrm{x} \times 6 \mathrm{x}$ crosses was lacking. In $5 \mathrm{x} \times 6 \mathrm{x}$ crosses, most individuals had chromosome numbers ranging between $2 n=5 x+6=66$ to $2 n=5 x+9=69$. Thus, breeding efforts attempting to transfer characteristics from tetraploid species to the hexaploid level will likely involve the use of aneuploids between the pentaploid and hexaploid chromosome levels.

The purpose of this study was to characterize the fertility of the aneuploids derived from backcrosses to the hexaploid parent species, $V$. ashei. Specifically, the objectives were to determine: 1) the effect of chromosome number on fertility and on variables representing measures of fertility and 2) the relative importance of general and specific combining ability, maternal, and reciprocal effects in the crossing behavior of these aneuploids.

\section{Materials and Methods}

Six aneuploids derived from $V$. ashei/V corymbosum pentaploid hybrids backcrossed to $V$. ashei, which varied in chromosome number, were selected from four different progenies. The ancestry of these aneuploids involved either or both of the two $V$. ashei $(2 \mathrm{n}=6 \mathrm{x}=72)$ cultivars Tifblue and Woodard and one of the two $V$. corymbosum $(2 \mathrm{n}=4 \mathrm{x}=48)$ cultivars Weymouth and Darrow. Aneuploids 7235-6 $(2 \mathrm{n}=5 \mathrm{x}+8=$ $68)$ and $7235-9(2 n=5 x+1=61)$ were derived from the backcross ('Woodard' $\times$ 'Weymouth') $)^{\# 1} \times$ 'Woodard'. Aneuploid 7245-14 $(2 n=5 x+4=64)$ was derived from the backcross ('Darrow' $x$ 'Tifblue') ${ }^{\# 1} \mathrm{x}$ 'Woodard.' Aneuploids $7246-2(2 \mathrm{n}=5 \mathrm{x}+6=66)$ and 7246-13 $(2 \mathrm{n}=5 \mathrm{x}+10=$ 70) were derived from the backcross 'Tifblue' $\times$ ('Woodard' $x$ 'Weymouth')" ${ }^{\# 1}$. Aneuploid 7247-9 $(2 \mathrm{n}=5 \mathrm{x}+2=62)$ was derived from the backcross 'Tifblue' $\times(\text { 'Darrow' } x \text { 'Tifblue' })^{\# 1}$. Plants were dug from the field and potted while dormant in Nov. 1986 and placed in a shaded (55\% shade) greenhouse maintained at a minimum of $1 \mathrm{C}$. When the greenhouse reached $5.5 \mathrm{C}$, exhaust fans were turned on to maintain cooler temper- 
atures. In Feb. 1987, plants were placed in a greenhouse maintained between 20 and $30 \mathrm{C}$ to bring plants into flowering.

For $\mathrm{BC}_{1} \times \mathrm{BC}_{1}$ crosses, a full diallel mating design was used; it consisted of 36 crosses (six self-pollinations and 30 crosspollinations). These aneuploids were also backcrossed as female parents to 'Tifblue' and 'Woodard' for the second backcross to $V$. ashei. They were also crossed as female parents to JU-2, an interspecific hexaploid hybrid derived from a $V$. ashei $\times V$. constablaei cross of unknown pedigree. For the $\mathrm{BC}_{2}$ crosses, the aneuploids were used as female parents.

For each $\mathrm{BC}_{1} \times \mathrm{BC}_{1}$ cross, 25 flowers were pollinated on each of three separate canes to give a total of 75 flowers pollinated for each cross, except for five crosses where only two canes were used, resulting in only 50 pollinated flowers. For the second backcrosses to hexaploids, $\mathrm{BC}_{1}$ aneuploids were used as females (75 flowers/cross). One to three canes were used for each cross: eight crosses (three canes), seven crosses (two canes), and three crosses (one cane). Flowers were emasculated 2 to 3 days before anthesis. Fresh pollen, collected 1 to $2 \mathrm{~h}$ before pollination, was applied to stigmas 4 to 5 days after emasculation.

Fruit was harvested as it ripened and was refrigerated until all fruit was harvested. For seed counts, 10 berries were selected at random from each cane' from each cross. Seed counts were taken on all fruit if fewer than 10 fruit were set on a cane. Canes (nine canes) for some crosses failed to set fruit. Total and developed seed, as defined by Bell (1957), were determined for each berry. Percent developed seed was calculated as developed/ total seeds/berry. Developed seed per pollination was calculated for each cane by the following equation: developed seed/pollination $=[($ mean developed seed/berry $) \times($ number of fruit set)] $/ 25$.

For $\mathrm{BC}_{1} \times \mathrm{BC}_{1}$ crosses, developed seed from fruit of each cane was bulked and split into two equal lots, except where there were fewer than 10 developed seed. In Ott. 1987, the five to six lots (three to 50 seed) of developed seed from each cross were assigned to one of six flats. A lot of 50 developed seed from each cane of the $\mathrm{BC}_{2}$ crosses was assigned to one of two flats. Each lot of seed was surface-sown on a 50 sphagnum : 50 sand $(\mathrm{v} / \mathrm{v})$ medium in a $5 \times 5-\mathrm{cm}$ randomly assigned section of the flat. Flats were placed under intermittent mist. The number of seedlings was counted at 14 weeks. Seedlings per pollination was calculated for each cane by the following equation: seedlings/pollination $=$ number of seedlings $/ 25$.

Statistical analysis. Data from the $\mathrm{BC}_{1} \times \mathrm{BC}_{1}$ crosses, selfpollinations excluded, were analyzed by regression and diallel analysis. Regression analysis used the general linear models (GLM) procedure of the Statistical Analysis System (SAS Institute, 1989) to determine the relationship between chromosome number and the fertility variables. A software program (Schaffer and Usanis, 1969) was used for the diallel analysis according to Griffing's method 3, Model 1 (Griffing, 1956). Multivariate analysis used RSQUARE within REG procedure in SAS (SAS Institute, 1989). Data from the $\mathrm{BC}_{2}$ crosses were analyzed with a factorial analysis of the GLM procedure of SAS (SAS Institute, 1989).

\section{Results}

Fruit set was extremely variable, ranging from $\mathrm{O}$ to $89 \%$ (Table 1). However, all six $\mathrm{BC}_{1}$ aneuploids in this study had the capacity for $>50 \%$ fruit set, indicating that the flowers and ovaries were functional. The maximum total seed per berry for each of the aneuploids ranged from 52.9 for aneuploid 7246-2
$(7246-2 \times 7246-13)$ to 93.2 for aneuploid 7246-13 (7246-13 $\times$ 'Tifblue'), suggesting that flowers of all aneuploids of this study produce more than 50 ovules per flower.

Fertility of $B C_{1} \times B C_{1}$ crosses. Percent fruit set of the $\mathrm{BC}_{1}$ $\times \mathrm{BC}_{1}$ crosses was extremely variable, ranging from as low as $1.0 \%(7235-6 \times 7245-14)$ to as high as $89.0 \%(7246-13 \times 7247-$ 9) (Table 1). Mean total seed per berry ranged from 29.7 (7235$9 \times 7245-14)$ to $90.3(7246-13 \times 7246-2)$, indicating all crosses had some level of fertilization. However, mean developed seed per berry ranged as low as $2.5(7247-9 \times 7245-14)$, resulting in only a $4 \%$ level of developed seed per berry, which suggests an abortion rate of $96 \%$ (Table 1); only one other cross, 7235$6 \times 7245-14$, had a lower value (3\%). Mean percent developed seed per berry ranged to a high of $38 \%(7235-9 \times 7246-13)$, suggesting that the majority $(>60 \%)$ of fertilized ovules abort in these crosses. Furthermore, developed seeds from some crosses $(7245-14 \times 7247-9)$ failed to germinate (Table 1$)$. The highest germination frequency of $77 \%$ was exhibited by the cross 7235 $6 \times 7247-9$. Mean developed seed per pollination ranged from less than one per pollination $(7235-6 \times 7245-14)$ to more than $16(7246-13 \times 7235-9)$. Mean seedlings per pollination ranged from $0(7245-14 \times 7247-9)$ to $10.5(7246-13 \times 7235-9)$.

Analysis of variance of the $6 \times 6$ diallel set of crosses indicated there were significant differences among the crosses for all seven fertility variables of this study (Table 2). A significant proportion of the variation could be accounted for by a linear relationship between the variables and chromosome number (midparental value). The proportion of crosses sum of squares that could be accounted for by regression ranged from $2.7 \%$ for percent developed seed per berry to $30.2 \%$ for total seeds per berry (Table 3 ). The variation among crosses not accounted for by regression, given as "remaining" in Table 2, was also significant. All regression slope coefficients (not given) were positive, indicating that all response variables increased with the midparent chromosome number (mean chromosome number of two parents) of the cross.

The same data analyzed with diallel analysis revealed that general combining ability (GCA) effects were significant for all variables, and except for percent developed seed per berry, GCA was the principal effect contributing to differences among crosses (Table 4). The proportion of crosses sum of squares accounted for by GCA ranged from $35.5 \%$ for percent developed seeds per berry to $69.7 \%$ for seedlings per pollination (Table 3 ).

Specific combining ability (SCA) effects were not significant (Table 4). Maternal effects were significant for total seed per berry, percent developed seed per berry, and percent seed germination (Table 4). Reciprocal effects, given maternal effects, were significant for percent fruit set, developed seed per pollination, and seedlings per pollination (Table 4). The largest reciprocal differences for developed seed per pollination involved crosses 7245-14 × 7246-2 and 7245-14 × 7246-13. The major contributing factors to these two reciprocity differences were differences in fruit set: the cross $7245-14 \times 7246-2$ had $44 \%$ fruit set, while the reciprocal cross set only $4 \%$, and the cross $7245-14 \times 7246-13$ had $88 \%$ fruit set, while the reciprocal cross set only $7 \%$ (Table 1 ).

Correlation analysis (self-pollinations excluded) between the response variables yielded all positive correlation coefficients (Table 5). Percent fruit set, total seed per berry, developed seed per berry, developed seed per pollination, and seedlings per pollination were all significantly correlated with one another. Percent developed seed per berry was significantly correlated to all response variables, except total seed per berry and percent 
Table 1. Mean percent fruit set (\%FS), total seed per berry (TS), developed seed per berry (DS), percent developed seeds per berry (\%DS), developed seed per pollination (DS/Poll), percent seed germination (\%Germ), and seedlings per pollination (S/Poll) for blueberry genotypes.

\begin{tabular}{|c|c|c|c|c|c|c|c|c|c|c|}
\hline \multirow[b]{2}{*}{ Female } & & \multirow[b]{2}{*}{ Pollen } & \multirow{2}{*}{$\frac{2 n^{z}}{\text { nale } x \text { male }}$} & \multirow[b]{2}{*}{$\% \mathrm{FS}$} & \multirow[b]{2}{*}{ TS } & \multirow[b]{2}{*}{ DS } & \multirow[b]{2}{*}{$\% \mathrm{DS}$} & \multirow[b]{2}{*}{$\%$ Germ } & \multirow[b]{2}{*}{ DS/Poll } & \multirow[b]{2}{*}{ S/Poll } \\
\hline & & & & & & & & & & \\
\hline \multicolumn{11}{|l|}{$\mathrm{BC}_{1} \times \mathrm{BC}_{1}$} \\
\hline \multirow[t]{6}{*}{$7235-6$} & $x$ & Self & $68 \times 68$ & 0 & $\cdots$ & --- & $\cdots$ & $\cdots$ & 0 & 0 \\
\hline & $x$ & $7235-9$ & $68 \times 61$ & 12 & 55.2 & 9.0 & 15 & 56 & 0.8 & 0.5 \\
\hline & $x$ & $7245-14$ & $68 \times 64$ & 1 & 45.0 & 4.0 & 3 & 50 & 0.1 & $<0.1$ \\
\hline & $x$ & $7246-2$ & $68 \times 66$ & 43 & 77.8 & 10.8 & 13 & 64 & 5.2 & 3.4 \\
\hline & $x$ & $7246-13$ & $68 \times 70$ & 48 & 67.9 & 9.9 & 15 & 59 & 5.6 & 3.3 \\
\hline & $x$ & $7247-9$ & $68 \times 62$ & 4 & 49.3 & 6.0 & 8 & 77 & 0.3 & 0.2 \\
\hline \multirow[t]{4}{*}{$7235-9$} & $x$ & Self & $61 \times 61$ & 35 & 50.1 & 7.2 & 14 & 45 & 1.3 & 0.6 \\
\hline & $x$ & $7235-6$ & $61 \times 68$ & 40 & 58.7 & 17.8 & 20 & 75 & 7.2 & 5.3 \\
\hline & $x$ & $7245-14$ & $61 \times 64$ & 7 & 29.7 & 3.3 & 6 & 58 & 0.2 & 0.1 \\
\hline & $x$ & $7246-2$ & $61 \times 66$ & 21 & 48.3 & 6.6 & 13 & 64 & 1.9 & 1.3 \\
\hline \multirow[t]{2}{*}{. } & $x$ & $7246-13$ & $61 \times 70$ & 48 & 64.4 & 24.9 & 38 & 68 & 11.6 & 7.5 \\
\hline & $x$ & $7247-9$ & $61 \times 62$ & 40 & 59.8 & 10.3 & 12 & 62 & 4.1 & 1.8 \\
\hline \multirow[t]{6}{*}{$7245-14$} & $x$ & Self & $64 \times 64$ & 0 & --- & --- & $\cdots$ & -- & 0 & 0 \\
\hline & $x$ & $7235-6$ & $64 \times 68$ & 5 & 46.3 & 8.0 & 6 & 50 & 0.4 & 0.2 \\
\hline & $x$ & $7235-9$ & $64 \times 61$ & 16 & 48.1 & 10.3 & 21 & 22 & 1.6 & 0.3 \\
\hline & $x$ & $7246-2$ & $64 \times 66$ & 44 & 47.1 & 7.8 & 16 & 29 & 3.6 & 0.7 \\
\hline & $x$ & $7246-13$ & $64 \times 70$ & 88 & 63.0 & 16.7 & 26 & 25 & 14.7 & 3.6 \\
\hline & $x$ & $7247-9$ & $64 \times 62$ & 3 & 52.5 & 7.0 & 9 & 0 & 0.2 & 0 \\
\hline $7246-2$ & $x$ & Self & $66 \times 66$ & 0 & --- & --- & --- & -.. & 0 & 0 \\
\hline & $x$ & $7235-6$ & $66 \times 68$ & 55 & 47.0 & 10.7 & 22 & 68 & 6.3 & 4.3 \\
\hline & $x$ & $7235-9$ & $66 \times 61$ & 71 & 45.5 & 12.0 & 25 & 74 & 9.7 & 6.7 \\
\hline & $x$ & $7245-14$ & $66 \times 64$ & 4 & 31.3 & 6.5 & 13 & 10 & 0.2 & $<0.1$ \\
\hline & $x$ & $7246-13$ & $66 \times 70$ & 82 & 52.9 & 15.4 & 29 & 57 & 12.4 & 7.5 \\
\hline & $x$ & $7247-9$ & $66 \times 62$ & 35 & 42.9 & 6.3 & 15 & 55 & 2.1 & 1.1 \\
\hline $7246-13$ & $x$ & Self & $70 \times 70$ & 88 & 80.7 & 8.8 & 11 & 57 & 7.8 & 4.4 \\
\hline & $x$ & $7235-6$ & $70 \times 68$ & 66 & 85.6 & 15.5 & 18 & 75 & 9.9 & 7.4 \\
\hline & $x$ & $7235-9$ & $70 \times 61$ & 85 & 82.7 & 20.0 & 24 & 65 & 16.6 & 10.5 \\
\hline & $x$ & $7245-14$ & $70 \times 64$ & 7 & 47.5 & 3.2 & 6 & 61 & 0.2 & 0.2 \\
\hline & $x$ & $7246-2$ & $70 \times 66$ & 89 & 90.3 & 16.8 & 12 & 67 & 14.9 & 6.6 \\
\hline & $x$ & $7247-9$ & $70 \times 62$ & 70 & 74.5 & 8.6 & 7 & 64 & 6.5 & 2.7 \\
\hline $7247-9$ & $x$ & Self & $62 \times 62$ & 0 & -.. & -- & --- & --- & 0 & 0 \\
\hline & $x$ & $7235-6$ & $62 \times 68$ & 24 & 47.7 & 6.9 & 14 & 49 & 1.6 & 0.8 \\
\hline & $x$ & $7235-9$ & $62 \times 61$ & 37 & 49.8 & 7.5 & 15 & 47 & 2.8 & 1.3 \\
\hline & $x$ & $7245-14$ & $62 \times 64$ & 7 & 42.4 & 2.5 & 4 & 17 & 0.2 & 0.4 \\
\hline & $x$ & $7246-2$ & $62 \times 66$ & 17 & 52.7 & 8.5 & 11 & 51 & 1.5 & 0.8 \\
\hline & $x$ & $7246-13$ & $62 \times 70$ & 52 & 54.7 & 14.6 & 27 & 42 & 8.0 & 3.5 \\
\hline $\mathrm{BC}_{2}$ crosses & & & & & & & & & & \\
\hline $7235-6$ & & NJUS-2 & $68 \times 72$ & 27 & 45.9 & 6.7 & 14 & 56 & 2.2 & 1.4 \\
\hline $7235-9$ & & NJUS-2 & $61 \times 72$ & -- & $\cdots$ & $\ldots$ & --- & -- & -- & $\cdots$ \\
\hline $7245-14$ & & NJUS-2 & $64 \times 72$ & 64 & 58.5 & 16.8 & 29 & 10 & 10.7 & 1.1 \\
\hline $7246-2$ & & NJUS-2 & $66 \times 72$ & 87 & 49.1 & 21.9 & 45 & 75 & 19.3 & 14.4 \\
\hline $7246-13$ & & NJUS-2 & $70 \times 72$ & 73 & 71.0 & 18.4 & 25 & 75 & 12.7 & 9.3 \\
\hline $7247-9$ & & NJUS-2 & $62 \times 72$ & 72 & 49.7 & 8.9 & 17 & 50 & 4.1 & 3.1 \\
\hline $7235-6$ & & Tifblue & $68 \times 72$ & 70 & 86.0 & 21.4 & 25 & 58 & 16.1 & 9.2 \\
\hline $7235-9$ & & Tifblue & $61 \times 72$ & 64 & 69.8 & 31.9 & 46 & 71 & 20.3 & 14.4 \\
\hline $7245-14$ & & Tifblue & $64 \times 72$ & 73 & 62.9 & 17.2 & 27 & 20 & 12.7 & 2.5 \\
\hline $7246-2$ & & Tifblue & $66 \times 72$ & 87 & 50.1 & 30.1 & 60 & 69 & 26.3 & 18.5 \\
\hline $7246-13$ & & Tifblue & $70 \times 72$ & 66 & 93.2 & 50.8 & 55 & 90 & 33.7 & 30.0 \\
\hline $7247-9$ & & Tifblue & $62 \times 72$ & 82 & 51.6 & 17.9 & 35 & 42 & 14.7 & 6.1 \\
\hline $7235-6$ & & Woodard & $68 \times 72$ & 37 & 65.0 & 7.5 & 12 & 58 & 2.8 & 1.6 \\
\hline $7235-9$ & & Woodard & $61 \times 72$ & $\cdots$ & $\ldots$ & $\ldots$ & $\cdots$ & -- & -- & -- \\
\hline $7245-14$ & & Woodard & $64 \times 72$ & 33 & 63.9 & 16.9 & 26 & 7 & 5.5 & 0.4 \\
\hline $7246-2$ & & Woodard & $66 \times 72$ & 65 & 36.8 & 16.1 & 46 & 69 & 10.5 & 7.2 \\
\hline $7246-13$ & & Woodard & $70 \times 72$ & 70 & 87.3 & 15.0 & 18 & 77 & 11.9 & 9.3 \\
\hline $7247-9$ & & Woodard & $62 \times 72$ & 77 & 52.1 & 18.1 & 35 & 51 & 13.8 & 7.1 \\
\hline
\end{tabular}

${ }^{\mathrm{z}}$ Chromosome numbers of the female and male parents in the cross.

seed germination. Percent seed germination was only significantly correlated to total seed per berry and seedlings per pollination.

The primary criterion concerning breeding programs is the efficiency of recovering progeny for future cycles of selection and breeding, which is most closely represented by the variable seedlings per pollination (S/Poll) in this study. Four variables that provide measures of fertility, and which could be consid- 
Table 2. Analysis of variance of a $6 \times 6$ diallel, self-pollinations excluded, set of blueberry crosses for percent fruit set (\%FS), total (TS) and developed (DS) seed per berry, percent developed seed per berry (\%DS), percent germination (\%Germ), developed seed per pollination (DS/Poll), and seedlings per pollination (S/Poll).

\begin{tabular}{|c|c|c|c|c|c|c|c|c|}
\hline \multirow[b]{2}{*}{ Source } & \multirow[b]{2}{*}{$\mathrm{df}$} & \multicolumn{7}{|c|}{ Mean square } \\
\hline & & $\% \mathrm{FS}$ & TS & DS & $\% \mathrm{DS}$ & $\%$ Germ & DS/Poll & S/Poll \\
\hline Crosses & 29 & $2,346^{* *}$ & $540^{* *}$ & $73.8^{*}$ & $141.4^{* *}$ & $1,686^{* *}$ & $75.2^{* *}$ & $29.3^{* *}$ \\
\hline Linear $^{z}$ & 1 & $13,736^{* *}$ & $4,730^{* *}$ & $282.5^{* *}$ & $110.8^{*}$ & $5,716^{* *}$ & $462.7^{* *}$ & $167.1^{* *}$ \\
\hline Remaining & 28 & $1,939^{* *}$ & $390^{* *}$ & $66.4^{* *}$ & $142.5^{* *}$ & $1,542^{* *}$ & $61.4^{* *}$ & $24.4^{* *}$ \\
\hline \multirow[t]{2}{*}{ Error $^{y}$} & 46 & & 111 & 14.0 & 24.7 & & & \\
\hline & $\begin{array}{r}55 \\
115\end{array}$ & 289 & & & & 324 & 8.6 & 3.3 \\
\hline
\end{tabular}

${ }^{2}$ Regression on midparent chromosome number (average chromosome number of parents).

${ }^{\mathrm{E} E r r o r} \mathrm{df}$ for \%FS, DS/Poll, and S/Poll derived from three ( 25 crosses) and two (five crosses) replicates, yielding a total $\mathrm{df}=85$. Error $\mathrm{df}$ for TS, DS, and \%DS derived from three (18 crosses), two (10 crosses), and one ( 2 crosses) replicate, yielding a total $\mathrm{df}=76$; nine canes failed to set fruit. Error $\mathrm{df}$ for \%Germ derived from six (16 crosses), four (six crosses), three (five crosses), and two (two crosses) replicates, yielding a total $\mathrm{df} \cdot=145$.

$*, * *$ Significant at $P=0.05$ and 0.01 , respectively.

Table 3. Percentage of crosses sum of squares that can be accounted for by: 1) linear regression on midparent chromosome number and 2) general combining ability (GCA) effects for a $6 \times 6$ diallel set of blueberry crosses (self-pollinations excluded).

\begin{tabular}{lcc}
\hline & \multicolumn{2}{c}{$\begin{array}{c}\text { Perccntage of crosses } \\
\text { sum of squares }\end{array}$} \\
\cline { 2 - 3 } Factor & Regression & GCA \\
\hline Percent fruit set & 20.2 & 51.8 \\
Total seed/berry & 30.2 & 54.0 \\
Developed seed/berry & 13.2 & 57.4 \\
Percent developed seed/berry & 2.7 & 35.5 \\
Percent seed germination & 11.7 & 67.0 \\
Developed seed/pollination & 21.2 & 66.1 \\
Seedlings/pollination & 19.6 & 69.7 \\
\hline
\end{tabular}

ered independent in this study, are percent fruit set (\%FS), total seed per berry (TS), percent developed seed per berry (\%DS), and percent seed germination (\%Germ). Multivariate regression analysis, where S/Poll is the dependent variable and \%FS, TS, $\% \mathrm{DS}$, and \%Germ represent the independent variables, could account for $85.6 \%\left(R^{2}=0.856\right)$ of the variation observed in S/Poll with the following model: $\mathrm{S} /$ Poll $=-5.37+5.06(\% \mathrm{FS})$ $+0.06(\mathrm{TS})+9.07(\% \mathrm{DS})+3.06(\% \mathrm{Germ})$. However, \%FS singly accounted for $75.6 \%$ of the variaton, while the remaining three variables, although significant, accounted for only $10 \%$ of the additional variation.

Fertility under self-pollination was generally reduced, as compared to intercrosses between $\mathrm{BC}_{1}$ individuals. Four of the six $\mathrm{BC}_{1}$ aneuploids failed to set fruit with self-pollination (Table 1). Aneuploids $7235-9$ and $7246-13$ had $35 \%$ and $88 \%$ fruit set, respectively. Depending on the fertility criteria, the self-pollination values for these two $\mathrm{BC}_{1}$ derivatives were reduced compared to the most fertile $\mathrm{BC}_{1} \times \mathrm{BC}_{1}$ crosses but equal to or more fertile than others, e.g., crosses with aneuploid 7245-14.

Fertility of $\mathrm{BC}_{2}$ crosses. In the second backcross to the hexaploids, significant effects due to both the pollen $\left(\mathrm{BC}_{2}\right.$ hexaploid) and the female $\left(\mathrm{BC}_{1}\right.$ derivative) parent were found for all fertility variables, except percent fruit set (Table 6). For developed seed per berry, percent developed seed per berry, developed seed per pollination, and seedlings per pollination, pollen $\times$ female interaction was also significant. Mean performance, as pollen parents, of each of the $\mathrm{BC}_{1}$ aneuploids in $\mathrm{BC}_{1} \times \mathrm{BC}_{1}$ crosses (self-pollinations excluded) and of the backcrosses to the hexaploids is given in Table 7. The second backcrosses tended to be more fertile than $\mathrm{BC}_{1} \times \mathrm{BC}_{1}$ crosses, which was most apparent with developed seed per berry, percent developed seed per berry, developed seed per pollination, and seedlings per pollination. Backcrosses with 'Tifblue' were generally the most fertile. Aneuploid 7246-13 $(2 n=5 x+10=$ 70) exhibited fertility similar to backcrosses with NJUS-2 and 'Woodard'.

\section{Discussion}

The crossability behavior of the $V$. ashei $\mathrm{BC}_{1}$ aneuploids in this study indicates that fertility of the first backcross generation

Table 4. Estimated variance components for general (gca) and specific (sca) combining ability, and maternal (mat) and reciprocal (recip) effects for percent fruit set (\%FS), total (TS) and developed (DS) seed per berry, percent developed seed per berry (\%DS), percent germination (\%Germ), developed seed per pollination (DS/Poll), and seedlings/pollination (S/Poll) for a $6 \times$ 6 diallel set of blueberry crosses.

\begin{tabular}{lccccccc}
\hline \hline $\begin{array}{l}\text { Variance } \\
\text { component }\end{array}$ & \%FS & TS & DS & \%DS & \%Gcrm & DS/Poll & S/Poll \\
\hline$\delta_{\text {gca }}$ & $373.2^{* *}$ & $77.99^{* *}$ & $10.66^{* *}$ & $12.0^{*}$ & $160.8^{*}$ & $12.19^{* *}$ & $4.85^{* *}$ \\
$\delta_{\text {sca }}$ & -18.4 & 3.59 & 3.00 & 4.1 & 1.8 & 0.59 & 0.94 \\
$\delta_{\text {mat }}$ & -2.4 & $25.61^{* *}$ & 1.59 & $10.4^{* *}$ & $21.4^{*}$ & -0.36 & -0.06 \\
$\delta_{\text {recip }}$ & $226.8^{* *}$ & 6.65 & 2.59 & 3.9 & 15.5 & $6.67^{* *}$ & $1.66^{*}$ \\
$\delta_{\text {error }}$ & 288.6 & 111.97 & 14.32 & 24.7 & 323.9 & 8.58 & 3.28 \\
\hline
\end{tabular}

*,**Significant at $P=0.05$ and 0.01 , respectively. 
Table 5. Correlation of percent fruit set (\%FS), total seed per berry (TS), developed seed per berry (DS), percent developed seed per berry (\%DS), percent seed germination (\%Germ), developed seed per pollination (DS/Poll), and seedlings per pollination (S/Poll) with one another for $30 \mathrm{BC}_{1} \times \mathrm{BC}_{1}$ blueberry crosses.

\begin{tabular}{|c|c|c|c|c|c|c|c|}
\hline & $\% \mathrm{FS}$ & TS & DS & $\% \mathrm{DS}$ & $\%$ Germ & DS/Poll & S/Poll \\
\hline$\% \mathrm{FS}$ & --- & $\begin{array}{r}0.68 \\
(<0.01)\end{array}$ & $\begin{array}{c}0.73 \\
(<0.01)\end{array}$ & $\begin{array}{c}0.62 \\
(<0.01)\end{array}$ & $\begin{array}{c}0.35 \\
\text { NS }\end{array}$ & $\begin{array}{c}0.94 \\
(<0.01)\end{array}$ & $\begin{array}{r}0.87 \\
(<0.01)\end{array}$ \\
\hline TS & & $\ldots$ & $\begin{array}{c}0.64 \\
(<0.01)\end{array}$ & $\begin{array}{l}0.24 \\
\text { NS }\end{array}$ & $\begin{array}{c}0.40 \\
(0.02)\end{array}$ & $\begin{array}{c}0.70 \\
(<0.01)\end{array}$ & $\begin{array}{c}0.73 \\
(<0.01)\end{array}$ \\
\hline DS & - & & $\cdots$ & $\begin{array}{c}0.83 \\
(<0.01)\end{array}$ & $\begin{array}{l}0.32 \\
\text { NS }\end{array}$ & $\begin{array}{c}0.87 \\
(<0.01)\end{array}$ & $\begin{array}{c}0.85 \\
(<0.01)\end{array}$ \\
\hline$\% \mathrm{DS}$ & & & & -- & $\begin{array}{c}0.16 \\
\text { NS }\end{array}$ & $\begin{array}{c}0.70 \\
(<0.01)\end{array}$ & $\begin{array}{r}0.62 \\
(<0.01)\end{array}$ \\
\hline$\%$ Germ & & & & & $\cdots$ & $\begin{array}{l}0.32 \\
\text { NS }\end{array}$ & $\begin{array}{r}0.51 \\
(<0.01)\end{array}$ \\
\hline DS/Poll & & & & & & ... & $\begin{array}{c}0.94 \\
(<0.01)\end{array}$ \\
\hline S/Poll & & & & & & & --- \\
\hline
\end{tabular}

is improved over that of the pentaploid hybrids (Jelenkovic and Draper, 1973), as was also found with aneuploids between the tetraploid and pentaploid levels derived from backcrosses to the tetraploid species $V$. corymbosum (Vorsa et al., 1987b). The crossing behavior of aneuploids of this study was similar to that of the $V$. corymbosum $\mathrm{BC}_{1}$ aneuploids in a few other aspects as well (Vorsa et al., 1987 b). In both studies, GCA was the principal effect contributing to differences in fertility among the crosses, followed by reciprocal differences.

Since fertility would, be expected to improve as the chromosome number approaches the hexaploid number of $2 \mathrm{n}=72$, it was not unexpected to find a positive relationship between chromosome number and fertility. However, the proportion of the variation among crosses accounted for by chromosome number was, at most, $30 \%$ for any one variable. Estimated GCA effects accounted for considerably more of the crosses sum of squares than did regression on mid-parental chromosome number (Table 3 ), suggesting factors other than chromosome number were as or more important in contributing to a plant's GCA for fertility. In this study, this relationship was most apparent with aneuploid 7235-9, which had a chromosome number of only one above the pentaploid number and yet was generally more fertile than a number of aneuploids (7246-2 and 7247-9) and was as fertile as aneuploid 7245-14, which were all closer to the hexaploid number.

From this standpoint, these results contrast with those of the
$V$. corymbosum $\mathrm{BC}_{1}$ aneuploids, where chromosome number was considered the major factor contributing to differences in fertility and was the principal component of GCA (Vorsa et al., 1987b). The reason for this difference is unclear. Khush (1973) has proposed that with increasing polyploidy, the effect of aneuploidy on fertility is buffered. The inability to recover aneuploids between the diploid and tetraploid levels in blueberry appears to support this explanation (Vorsa and Ballington, 1991). Thus, the reduced relationship between fertility and chromosome number may be a reflection of the additional genome in $V$. ashei $\mathrm{BC}_{1}$ aneuploids, which have a minimum of five complete genomes, as opposed to $V$. corymbosum $\mathrm{BC}_{1}$ aneuploids, which have a minimum of four genomes. However, this situation would not explain the relatively high fertility of aneuploid 7235-9.

Variation in fruit set among crosses would be expected to contribute toward differences in fertility, as measured by developed seed per pollination and seedlings per pollination. Since percent fruit set could account for $75.6 \%$ of the observed variation in seedlings per pollination, it would appear to be a major factor influencing fertility among the crosses of this study. One factor effecting level of fruit set could be genotypic variability in the threshold number of developing seed needed for an ovary to develop to maturity. Variability among plants in their ability to set fruit would also likely give rise to significant reciprocal effects, which were observed in this study.

SCA effects were not significant, suggesting that genotype $\times$ genotype interactions were not a factor in the fertility of the $\mathrm{BC}_{1} \times \mathrm{BC}_{1}$ crosses, as was also found with the $V$. corymbosum $\mathrm{BC}_{1}$ aneuploids (Vorsa et al., 1987b). However, in the second backcrosses to hexaploids, the significant pollen $\mathrm{x}$ female interaction for four of the variables, including seedlings per pollination, suggested there was a significant genotype $\times$ genotype interaction. A possible contributing factor to the interaction could be the level of inbreeding associated with the cross: inbreeding level has been shown to be negatively correlated with fertility in both $V$. corymbosum and $V$. ashei crosses (Hellman and Moore, 1983; Krebs and Hancock, 1988). For example, crosses 7235$6 \times$ 'Woodard' and 7247-9 × 'Tifblue' are second backcrosses to the same recurrent parent and have inbreeding coefficients of $F=0.375$. The 7235-6 $\times$ 'Woodard' backcross appears to have reduced fertility, but only when compared to outcross 7235-6 $\times$ 'Tifblue' (Table 1). Due to the confounding nature of the varying $\mathrm{BC}_{1}$ chromosome numbers in this study, effects due to inbreeding in $\mathrm{BC}_{1} \times \mathrm{BC}_{1}$ crosses are difficult to ascertain.

Variation among crosses for total seed per berry suggest dif-

Table 6. Analysis of variance for percent fruit set (\%FS), total seed per berry (TS), developed seed per berry (DS), percent developed seed per berry (\%DS), developed seed per pollination (DS/Poll), percent germination (\%Germ), and seedlings per pollination (S/Poll) for $\mathrm{BC}_{1} \mathrm{x}$ hexaploid blueberry crosses.

\begin{tabular}{lrccccccc}
\hline & \multicolumn{7}{c}{ Mean squares } \\
\cline { 2 - 8 } Factor & df & $\% \mathrm{FS}$ & TS & DS & $\%$ DS & $\%$ Germ & DS/Poll & S/Poll \\
\hline Pollen $^{2}$ & 2 & 0.10 & $563^{*}$ & $633^{* *}$ & $0.076^{* *}$ & 0.003 & $541^{* *}$ & $253^{* *}$ \\
Female $^{x}$ & 5 & $0.13^{*}$ & $1112^{* *}$ & $213^{* *}$ & $0.060^{* *}$ & $0.322^{* *}$ & $164^{* *}$ & $218^{* *}$ \\
Pollen $^{*} \times$ female & 8 & 0.04 & 197 & $142^{* *}$ & $0.017^{* *}$ & 0.008 & $60^{*}$ & $55^{* *}$ \\
Error $^{y}$ & 20 & & 152 & 32 & & & 25 & 13 \\
\hline
\end{tabular}

${ }^{2}$ Hexaploid as pollen parent.

${ }^{\times} \mathrm{BC}_{1}$ aneuploid as female.

yThree crosses failed to set fruit; $\mathrm{df}=20$.

*,**Significant at $P=0.05$ and 0.01 , respectively. 
Table 7. Mean (range) performance of $\mathrm{BC}_{1}$ aneuploids and hexaploids as pollen parents in $\mathrm{BC}_{1} \times \mathrm{BC}_{1}$ and $\mathrm{BC}_{1} \times$ hexaploid blueberry crosses, respectively, for percent fruit set (\%FS), total seed per berry (TS), developed seed per berry (DS), percent developed seed per berry (\%DS), developed seed per pollination (DS/Poll), percent germination (\%Germ), and seedlings per pollination (S/Poll). (Note: $\mathrm{BC}_{1}$ self-pollinations excluded.)

\begin{tabular}{|c|c|c|c|c|c|c|c|c|c|}
\hline \multirow{2}{*}{$\begin{array}{l}\text { Pollen } \\
\text { parent }\end{array}$} & \multirow[b]{2}{*}{$2 \mathrm{~N}$} & \multirow{2}{*}{$\begin{array}{c}\text { No. } \\
\text { crosses }^{2}\end{array}$} & \multicolumn{7}{|c|}{ Mean (range) of crosses } \\
\hline & & & $\% \mathrm{FS}$ & $\mathrm{TS}$ & DS & $\% \mathrm{DS}$ & $\% \mathrm{Germ}$ & DS/Poll & S/Poll \\
\hline \multicolumn{10}{|l|}{$\mathrm{BC}_{1}$ aneuploids } \\
\hline $7235-6$ & 68 & 5 & $38(5-56)$ & $57(46-86)$ & $12(7-18)$ & $16(6-22)$ & $63(49-75)$ & $5.1(<1-10)$ & $3.6(<1-7)$ \\
\hline $7235-9$ & 61 & 5 & $44(12-85)$ & $56(46-83)$ & $12(8-20)$ & $20(15-25)$ & $53(22-74)$ & $6.3(<1-17)$ & $3.9(<1-11)$ \\
\hline $7246-2$ & 66 & 5 & $43(17-89)$ & $63(47-90)$ & $10(7-17)$ & $13(11-16)$ & $55(29-67)$ & $5.4(2-15)$ & $2.6(<1-7)$ \\
\hline $7247-9$ & 66 & 5 & $30(3-70)$ & $56(43-75)$ & $8(6-10)$ & $10(7-15)$ & $52(0-77)$ & $2.6(<1-7)$ & $1.2(0-3)$ \\
\hline $7245-14$ & 64 & 5 & $5(1-7)$ & $39(30-48)$ & $4(3-7)$ & $6(3-13)$ & $39(10-61)$ & $0.2(<1)$ & $0.2(<1)$ \\
\hline $7246-13$ & 70 & 5 & $64(48-88)$ & $61(53-68)$ & $16(10-25)$ & $27(15-38)$ & $50(25-68)$ & $10.5(6-15)$ & $5.1(3-8)$ \\
\hline \multicolumn{10}{|l|}{ Hexaploids } \\
\hline NJUS-2 & 72 & 5 & $65(27-87)$ & $55(46-71)$ & $15(7-22)$ & $26(14-45)$ & $53(10-75)$ & $9.8(2-19)$ & $5.9(1-14)$ \\
\hline Tifblue & 72 & 6 & $74(64-87)$ & $69(50-93)$ & $28(17-51)$ & $41(25-60)$ & $58(20-90)$ & $20.6(13-34)$ & $13.5(20-90)$ \\
\hline Woodard & 72 & 5 & $56(33-77)$ & $61(37-87)$ & $15(8-18)$ & $27(12-46)$ & $52(7-77)$ & $8.9(3-14)$ & $5.1(<1-9)$ \\
\hline
\end{tabular}

- Self-pollinations not included.

ferences in levels of fertilization, which may reflect selection at the gametophytic level (Vorsa et al., 1987b). Variation among crosses for percent developed seed per berry and percent germination suggests that postzygotic selection also contributes to differences in fertility among these crosses. Postzygotic selection can arise from mechanisms that involve endosperm factors and/or zygote viability. In crosses where aneuploid gametes are generated, postzygotic selection could result from chromosomal imbalance of zygotes or nonviable endosperm balance numbers (Vorsa, 1988). Since the aneuploids of this study, as well as those in Versa et al. (1987a), were generally vigorous, factors associated with the endosperm appear likely. Endosperm factors most likely contribute to the relative infertility of heteroploid crosses in blueberry (Darrow and Camp, 1945) and were considered to be significant in shaping the chromosomal constitutions of the backcross progenies from which the aneuploids of this study were selected, as well as those derived from backcrosses to the tetraploid species (Versa, 1988).

Since the $V$. ashei $\mathrm{BC}_{1}$ progenies consist predominantly of aneuploids (Versa, 1988), the use of aneuploids for further breeding cycles would be likely. Only one cross (7245-14 x 7247-9) out of 30 failed to produce any progeny in this study, and 17 of 30 produced more than one seedling per flower pollinated. Thus, the efficiency in producing progeny in $\mathrm{BC}_{1} \times$ $\mathrm{BC}_{1}$ crosses is variable. The second backcrosses to the hexaploid level were generally more fertile than the $\mathrm{BC}_{1} \times \mathrm{BC}_{1}$ crosses, indicating that introgression of $V$. corymbosum genes into $V$. ashei should not be problematic.

Only two of the six $V$. ashzei $\mathrm{BC}_{1}$ aneuploids of this study set fruit and yielded progeny with self-pollination. In contrast, all six $V$. corymbosum $\mathrm{BC}_{1}$ aneuploids (Vorsa et al., 1987b) set fruit and yielded viable progeny with self-pollination. This result is what might be expected, since $V$. ashei is considered to have higher self-sterility than $V$. corymbosum (El-Agamy et al., 1981 ), and these aneuploids would be $\approx 80 \% \mathrm{~V}$. ashei in their background.

In conclusion, this study substantiates earlier suggestions that pentaploid hybrids between $V$. ashei and $V$. corymbosum can be used for bilateral transfer of characteristics between these two species. Since it has been shown that at least two-thirds of the $V$. ashei genome can pair and recombine with that of $V$. corymbosum (Vorsa, 1987a) and that pairing in $V$. ashei $\mathrm{BC}_{1}$ hybrids is essentially regular (Vorsa, 1987b), it should be possible to introgress desirable genes into either species from the other.

\section{Literature Cited}

Bell, H.P. 1957. The development of blueberry seed. Can. J. Bot. 35:139153.

Darrow, G.M. and W.H. Camp. 1945. Vaccinium hybrids and the development of new horticultural material. Bul. Torrey Club 72:1-21.

El-Agamy, S.Z., W.B. Sherman, and P.M. Lyrene. 1981. Fruit set and seed number from self- and cross-pollinated highbush (4x) and rabbiteye (6x) blueberries. J. Amer. Soc. Hort. Sci. 106:443-445.

Galletta, G.J. 1975. Blueberries and cranberries, p. 154-196. In: J. Janick and J.N. Moore (eds.). Advances in fruit breeding. Purdue Univ. Press, West Lafayete, Ind.

Griffing, B. 1956. Concept of general and specific combining ability in relation to diallel crossing systems. Austral. J. Biol. Sci. 9:463-493.

Hellman, E.W. and J.N. Moore. 1983. Effect of genetic relationship to pollinizer on fruit, seed and seedling parameters in highbush and rabbiteye blueberries. J. Amer. Soc. Hort. Sci. 108:401-405.

Jelenkovic, G. and A.D. Draper. 1973. Breeding value of pentaploid interspecific hybrids of Vaccinium. J. Yugoslav Pomol. 25-26:237-244.

Khush, G.S. 1973. Morphology, anatomy, physiology, and biochemistry of trisomics, p. 131-151. In: Cytogenetics of aneuploids. Academic, New York.

Krebs, S.L. and J.F. Hancock. 1989. The consequences of inbreeding on fertility in Vaccinium corymbosum L. J. Amer. Soc. Hort. Sci. 113:914918.

SAS Institute, Inc. 1989. SAS/STAT user's guide, version 6 edition. SAS Inst., Inc., Cary, N.C.

Schaffer, H.E. and R.A. Usanis. 1969. General least square analysis of diallel experiment: A computer program diallel. North Carolina State Univ. Genetics Dept. Rpt. 1.

Vorsa, N. 1987a. Meiotic chromosome pairing and irregularities in blueberry interspecific $\mathrm{BC}_{1}$ hybrids. J. Hered. 78:395-399.

Vorsa, N. 1987b. Cytogenetic analyses of Vaccinium adrei $\times($ V. ashei $\times$ $V$. corymbosum) hybrids. HortScience 22:180-181. (Abstr.)

Vorsa, N. 1988. Differential transmission of extra genome chromosomes in pentaploid blueberry. Theor. Applied Genet. 75:585-591.

Vorsa, N. and J.R. Ballington. 1991. Fertility of triploid highbush blueberry. J. Amer. Soc. Hort. Sci. 116:336-342.

Vorsa, N., G. Jelenkovic, A.D. Draper, and W.V. Welker. 1987a. Fertility of $4 \mathrm{x} \times 5 \mathrm{x}$ and $5 \mathrm{x} \times 4 \mathrm{x}$ progenies derived from Vaccinium ashei/corymbosum pentaploid hybrids. J. Amer. Soc. Hort. Sci. 112(6):993-997.

Vorsa, N., G. Jelenkovic, A.D. Draper, and G.J. Galletta. 1987b. Crossability of $\mathrm{BC}_{1}$ aneuploid and tetraploid progeny derived from Vaccinium ashei/corymbosum pentaploid hybrids. J. Amer. Soc. Hort. Sci. 112(6):998-1004. 